\title{
European Grants \\ For Investment In Regional SMEs: The Case Of Castilla-La Mancha (Spain)
}

\author{
Manuel Vargas-Vargas, University of Castilla-La Mancha, Spain \\ José Mondéjar-Jiménez, University of Castilla-La Mancha, Spain \\ Juan-Antonio Mondéjar-Jiménez, University of Castilla-La Mancha, Spain \\ María-Leticia Meseguer-Santamaría, University of Castilla-La Mancha, Spain
}

\begin{abstract}
Public initiatives to assist the sustainable development of the rural environment are of great significance in the Spanish region of Castilla-La Mancha, which is faced with important socioeconomic changes that will undoubtedly condition the future of the rural environment. In these latter fields, the experience acquired in the Rural Innovation Programmes (Spanish acronym: PIR) carried out so far is of particular relevance. The intention of this study is to analyse the impact of the line known as 1.06, which is meant to support small enterprises (SMEs) and services in the general context of rural innovation programmes. For the empirical work, the chosen territory was the Autonomous Community of Castilla-La Mancha during the programme period 2002-2006 (LEADER + and PRODER II) for which there is data on the implementation of the financial tables from 2006. The incidence of the aforementioned programmes is analysed using the shift-share methodology, which allows to identify the different effects (global, structural and competitive) into which financial implementation may be divided.
\end{abstract}

Keywords: Shift-share, rural innovation programmes, small enterprises

\section{INTRODUCTION}

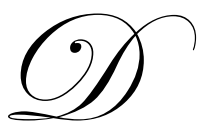

isadvantaged rural areas occupy a significant part of Spanish territory and by extension, most of the European Union. This is the reason why there have been efforts to promote endogenous rural development on the basis of territorial vertebration policies, translating into major economic efforts, but especially aimed at developing measures to support these regions. The year 1991 saw the launch of the EU Initiative LEADER, proposed by the European Commission (Mondéjar, Mondéjar, Vargas and Meseguer, 2008). This name represents the successive EU initiatives for rural development in the European Union. In French, it stands for "Liaisons entre activités de Developement de L'Economie Rural"; in other words, "Relations between Rural Economy Development Activities" (Ministry of Agriculture, Fisheries and Food, 2008). To be specific, "the EU Initiative LEADER is a new way of addressing rural development on the basis of a work methodology that forms local action groups at a county level to analyse the problems, weak points, strong points and opportunities in their territories with a view to designing their own development strategies and proposing them to the local and regional administrations" (García, Febles and Zapata 2005). This EU Initiative LEADER I was followed by the LEADER II programme, along with the Operational Programme for Economic Development and Diversification in Rural Areas (PRODER), which was carried out by the Government of Spain for the budgetary implementation in accordance with the philosophy and methodology of the LEADER programme (Mondéjar, Mondéjar and Vargas, 2008b).

In short, this is the most important Rural Development Policy implemented by the Member States of the European Union with a view to promoting the rural environment. Thus, in the last period of the programme, between 2002-2006, both the Commission and the Government of Spain decided to continue their support for these instruments via the LEADER + Initiative and the PRODER 2 Programme (Abad 2006). 
Thus, for the new period of implementation of the EU Initiative LEADER and the PRODER Development Programme (LEADER + and PRODER 2), the main aim will be to activate and consolidate sustainable development of the rural environment in the medium and long term. To this end, ten lines of investment have been established for the support measures involved in the development strategy, as may be seen in Table 1 (Vargas and Mondéjar 2006).

Table 1: Development Strategies in Rural Innovation Programmes

\begin{tabular}{|c|c|}
\hline OPERATIONAL CONTENT & LEADER+ AND PRODER 2 \\
\hline Acquisition of skills & 1.01 \\
\hline Services to the population & 1.02 \\
\hline Natural heritage & 1.03 \\
\hline Valuation of local agricultural produce & 1.04 \\
\hline SMEs and services & 1.06 \\
\hline Valuation of cultural and architectonic heritage & 1.07 \\
\hline Tourism & 1.08 \\
\hline Other investments & 1.09 \\
\hline Training and employment & 1.10 \\
\hline
\end{tabular}

Source: Department of the Environment and Rural Development.

The investment priorities of the Local Action Groups (Spanish acronym: GAL) are revealed in the percentage distribution of the funds, especially in the portion that is aimed at SMEs and services, as seen in the Table 2. Moreover, the investment location coefficients are included for this specific measure: these coefficients compare the proportion of capital invested by the group with the same proportion throughout the region. Values above one unit would indicate that the measure in question was of greater importance than the rest, while values below one unit would indicate a lower relative repercussion of the measure in the particular group.

If we also analyse the location coefficient of the various assistance measures in each programme, we will be able to obtain a comparison between the proportion of capital invested by the group and the same proportion throughout the region. Values above one unit indicate that the particular measure is more important, while values below one unit reveal a lower relative repercussion of the measure in the particular group. This information may be used to build investment "profiles" for each local action group, reflecting in which expenditure measures it has specialised, as may be seen in the Table 2 (Mondéjar, Mondéjar and Vargas, 2008b).

Line 1.06 for SMEs and services accounts, in some counties for over one-third of the programme's total investment, continuing the investment pattern of the 1996-2001 period and revealing the importance of these activities for the sustainable development of the rural environment in Castilla-La Mancha (Alfaro, Mondéjar and Vargas 2004). As may be seen from this data, 16 counties throughout the region have exceeded the Autonomous Community average with regard to the measure of supporting small enterprises and services. This detail is especially noteworthy as they have been capable of generating a very significant amount of private investment and also increase employability levels in their respective counties. This investment effort by the public administrations has been accompanied by the commitment of agents in the rural environment who are undertaking substantially high private expenditure in the majority of projects in Castilla-La Mancha. For the programme period 2002 to 2006, the initial investment planned in the Rural Innovation Programmes rose to 274.21 million euros (Mondéjar, Mondéjar and Vargas, 2008a). Of this capital, almost 60\% (a total of approximately 162 million euros) corresponds to public initiative, distributed among the Spanish administrations (national, autonomous and local) - almost $21 \%$ - and the European administrations, which represents almost $40 \%$ of expected investment. In turn, the initial expected participation of private initiative reaches almost $40 \%$ (just over 112 million euros). Therefore, the so-called "demonstration effect" has occurred, which leads to private investment along with public aid, materialising in new projects and initiatives in the same direction (Vargas and Mondéjar 2006) and making rural tourism one of the pillars of harmonious, balanced and sustainable development. 
Table 2: Analysis of the Measure SMEs and Services in Castilla-La Mancha

\begin{tabular}{|c|c|c|c|c|c|c|c|}
\hline \multicolumn{4}{|c|}{ Percentage of measure 1.06 of total } & \multicolumn{3}{c|}{ Location coefficient } \\
\hline Sier. Segura & $27.57 \%$ & Adiman & $31.22 \%$ & Sier. Segura & 0.7 & Adiman & 1.2 \\
\hline C. Hellín & $36.46 \%$ & Alcarria conq. & $33.57 \%$ & C. Hellín & 1.3 & Alcarria conq. & 1.1 \\
\hline Mancha Júcar & $45.27 \%$ & Záncara & $26.70 \%$ & Mancha Júcar & 1.5 & Záncara & 1.3 \\
\hline Manchuela & $31.87 \%$ & Adesiman & $31.41 \%$ & Manchuela & 0.9 & Adesiman & 1.1 \\
\hline Monte Ibérico & $35.28 \%$ & Fadeta & $34.92 \%$ & Monte Ibérico & 1 & Fadeta & 1.3 \\
\hline Sacam & $21.72 \%$ & Molina & $25.33 \%$ & Sacam & 0.5 & Molina & 0.9 \\
\hline Montesur & $26.61 \%$ & Adel & $22.70 \%$ & Montesur & 1 & Adel & 0.7 \\
\hline Calatrava & $17.69 \%$ & Adac & $39.43 \%$ & Calatrava & 0.8 & Adac & 1.3 \\
\hline Valle Alcudia & $20.63 \%$ & Quijote & $39.94 \%$ & Valle Alcudia & 0.4 & Quijote & 1.2 \\
\hline Guadiana & $26.16 \%$ & Adecor & $43.65 \%$ & Guadiana & 0.8 & Adecor & 1.6 \\
\hline Montes Norte & $17.61 \%$ & Dulcinea & $31.82 \%$ & Montes Norte & 0.7 & Dulcinea & 1.2 \\
\hline Promancha & $43.81 \%$ & Ipeta & $41.72 \%$ & Promancha & 0.7 & Ipeta & 0.7 \\
\hline Tierra libertad & $24.04 \%$ & Castillos & $55.76 \%$ & Tierra libertad & 0.7 & Castillos & 2.1 \\
\hline Cabañeros & $24.89 \%$ & Montes Toledo & $43.80 \%$ & Cabañeros & 0.9 & Montes Toledo & 1.3 \\
\hline Prodese & $21.30 \%$ & Autonomous & $31.96 \%$ & Prodese & 0.5 & Autonomous & $\mathbf{1}$ \\
\hline
\end{tabular}

Source: Study data based on data provided by the Regional Government of Castilla-La Mancha

\section{EMPIRICAL STUDY}

Taking into consideration the lines of support established in the EU Initiative LEADER + and the Operational Programme PRODER 2 (Table 1), this work analyses measure 1.06 to support small enterprises and services. The fact is that this set of measures configures one of the three basic pillars of grants in the scope of the programmes, as well as the line of tourism (Gómez, Mondéjar, Mondéjar and Monsalve 2007) and for heritage support (Esteban, Mondéjar, Mondéjar and Meseguer, 2008). In order to go further into the study of the capacity of the SMEs and Services measure to capture capital and how the effort is distributed on a spatial basis, we chose to carry out a shift-share analysis, a technique that is used in regional statistical analysis and that allows to quantify the effects associated to the different structure of the counties in Castilla - La Mancha and the "competitiveness" of local development agents in attracting private capital towards enhancement initiatives (Esteban, Mondéjar, Mondéjar and Meseguer, 2008).

Shift-share analysis was developed by Dunn (1960) as a method for calculating the components that explain the variations in economic magnitudes. According to Dunn (1960), "the essential component in this statistical technique is to calculate geographical changes in the evolution of the economy".

If $K_{i j}$ is used to denote the initial expected capital corresponding to measure $\mathrm{i}(i=1, \ldots, s)$ for the county $\mathrm{j}$ $(j=1, \ldots, r)$ in the initial instance and $K_{i j}^{\prime}$ the capital committed in this measure and county in the final instance, then the variation recorded (degree of financial implementation) may be expressed by the following equation (Mayor, López and Pérez 2005):

$$
K_{i j}^{\prime}-K_{i j}=\Delta K_{i j}=K_{i j} r+K_{i j}\left(r_{i}-r\right)+K_{i j}\left(r_{i j}-r_{i}\right)
$$

where:

$$
r=\frac{\sum_{i=1}^{s} \sum_{j=1}^{r}\left(K_{i j}^{\prime}-K_{i j}\right)}{\sum_{i=1}^{s} \Sigma_{j=1}^{r} K_{i j}} \quad r_{i}=\frac{\sum_{j=1}^{r}\left(K_{i j}^{\prime}-K_{i j}\right)}{\sum_{j=1}^{r} K_{i j}} \quad r_{i j}=\frac{K_{i j}^{\prime}-K_{i j}}{K_{i j}}
$$

and the three addends into which the global variation of the magnitude under study may be broken down as follows: 


$\begin{array}{ll}\text { Global Effect } & E G_{i j}=K_{i j} r \\ \text { Structural Effect } & E E_{i j}=K_{i j}\left(r_{i}-r\right) \\ \text { Competitive Effect } & E C_{i j}=K_{i j}\left(r_{i j}-r\right)\end{array}$

As may be seen in this breakdown (Table 3), as well as the inertia represented by the global effect (Spanish acronym: EG), we have to consider the contributions toward growth (positive or negative) that are derived from factors specific to each spatial field, which are represented by the sum of the Structural Effect and the Competitive Effect and usually referred to as the net effect. The structural effect describes the positive or negative influence on growth by the different relative importance of the heritage lines, with growth rates above or below the regional average, respectively, possibly associated to the possibilities of each county's cultural heritage. In turn, the competitive effect describes the particular dynamism of a county with regard to the regional level in each line and would therefore constitute a measure of the county's "success" in capturing capital for the SMEs and services line.

Table 3: Results Per Group, Shift-Share Analysis

\begin{tabular}{|c|c|c|c|c|c|}
\hline $\begin{array}{l}\text { Local Action Group } \\
\text { (GAL) }\end{array}$ & $\begin{array}{l}\text { Global } \\
\text { Effect }\end{array}$ & $\begin{array}{l}\text { Structural } \\
\text { Effect }\end{array}$ & $\begin{array}{l}\text { Competitive } \\
\text { Effect }\end{array}$ & $\begin{array}{c}\text { Actual } \\
\text { Variation }\end{array}$ & $\begin{array}{c}\text { Actual } \\
\text { Variation/ } \\
\text { Global Effect }\end{array}$ \\
\hline Sier. Segura & 576,756 & 987,404 & $-1,505,942$ & 58,218 & 0.101 \\
\hline C. Hellín & 537,702 & 920,543 & 323,375 & $1,781,621$ & 3.313 \\
\hline Mancha Júcar & $1,085,014$ & $1,857,539$ & $-761,596$ & $2,180,956$ & 2.01 \\
\hline Manchuela & 450,216 & 770,767 & $1,532,489$ & $2,753,472$ & 6.116 \\
\hline Monte Ibérico & 353,242 & 604,749 & $1,345,426$ & $2,303,417$ & 6.521 \\
\hline Sacam & 499,017 & 854,315 & $-416,709$ & 936,623 & 1.877 \\
\hline Montesur & 460,722 & 788,755 & $-686,721$ & 562,756 & 1.221 \\
\hline Calatrava & 257,303 & 440,501 & $-140,158$ & 557,646 & 2.167 \\
\hline Valle Alcudia & 274,663 & 470,222 & $-328,629$ & 416,256 & 1.516 \\
\hline Guadiana & 465,639 & 797,172 & $-750,814$ & 511,997 & 1.1 \\
\hline Montes Norte & 360,697 & 617,512 & $-790,814$ & 187,396 & 0.52 \\
\hline Promancha & 495,967 & 849,093 & 286,211 & $1,631,271$ & 3.289 \\
\hline Tierra libertad & 413,736 & 708,314 & $-695,290$ & 426,760 & 1.031 \\
\hline Cabañeros & 228,372 & 390,973 & $-175,420$ & 443,925 & 1.944 \\
\hline Prodese & 531,156 & 909,337 & $-663,587$ & 776,906 & 1.463 \\
\hline Adiman & 655,201 & $1,121,702$ & 342,844 & $2,119,747$ & 3.235 \\
\hline Alcarria conq. & 720,593 & $1,233,652$ & $-56,727$ & $1,897,518$ & 2.633 \\
\hline Záncara & 745,091 & $1,275,593$ & 81,333 & $2,102,017$ & 2.821 \\
\hline Adesiman & 800,193 & $1,369,927$ & $-1,829,679$ & 340,440 & 0.425 \\
\hline Fadeta & 760,050 & $1,301,202$ & $1,419,968$ & $3,481,220$ & 4.58 \\
\hline Molina & 642,871 & $1,100,593$ & $-150,112$ & $1,593,352$ & 2.478 \\
\hline Adel & 605,954 & $1,037,390$ & $-1,327,923$ & 315,422 & 0.521 \\
\hline Adac & 746,562 & $1,278,111$ & $-295,451$ & $1,729,222$ & 2.316 \\
\hline Quijote & 604,594 & $1,035,063$ & $-158,949$ & $1,480,708$ & 2.449 \\
\hline Adecor & 575,258 & 984,840 & 638,626 & $2,198,724$ & 3.822 \\
\hline Dulcinea & 536,744 & 918,903 & 217,195 & $1,672,842$ & 3.117 \\
\hline Ipeta & 750,006 & $1,284,007$ & $-430,804$ & $1,603,209$ & 2.138 \\
\hline Castillos & 687,534 & $1,177,056$ & $1,563,041$ & $3,427,632$ & 4.985 \\
\hline Montes Toledo & 462,998 & 792,650 & $1,650,370$ & $2,906,018$ & 6.277 \\
\hline
\end{tabular}

By calculating the effects of the classical shift-share model and adding them for each county, we would obtain an estimation of the global, structural and competitive effects depicted in Table 3, which also presents the actual variation in capital compared to what was initially expected and the degree of financial implementation expected if we only consider the global effect. 
In order to correctly interpret the actual variation in expected and committed capital, it is necessary to carry out a detailed analysis of the structural and competitive effects. Therefore, the structural effect has a positive value in all of the counties, with a more heterogeneous effect in the provinces, which does not allow us to reach conclusions on behavioural patterns. In turn, the competitive effect has a negative value in 18 groups and positive in only 10 groups, which reveals the more significant implication in terms of heritage of the groups mentioned compared to the regional total. If we take into account the quotient between the actual variation and the global effect, it reveals positive values in all groups, which may have a positive repercussion on the creation of entrepreneurial fabric in the provinces. In this regard, just four groups obtain values below one unit, which indicates a worse performance than initially expected by the group in its investments as a whole, which confirms the investments of line 1.08 in tourism (Gómez, Mondéjar, Mondéjar and Monsalve 2007).

\section{CONCLUSIONS}

This project has specifically considered measure 1.06 for rural tourism in the context of the application of rural development programmes in the Spanish region of Castilla-La Mancha, particularly the EU Initiative LEADER + and the Operational Programme PRODER II, which have covered practically the entire autonomous territory following the previous experiences of LEADER II, PRODER and before the latter, LEADER I.

These are initiatives that enhance most of the territorial resources in European regions while also representing a "demonstration effect" in local economies, with the intention of boosting certain rural areas - which sometimes are very much behind other regions, such as urban areas.

Moreover, the strategic investment lines are aspects that are highly relevant in the scope of actual territorial development as they lay the foundations in the medium and long term for promoting particularly disadvantaged rural areas. In this regard, the degree to which each of the lines of investment is taken into consideration reveals the importance granted to these different fields.

Once again, measure 1.06 to support SMEs and services and measure 1.08 for tourism were the ones that concentrated the most funds due to their capacity to mobilize private capital. As we have seen before, the fact that before the closure of the programme, 18 counties had certified over $100 \%$ of the initially planned investment, which leads us to believe that all of the groups will exceed this initial expectation. Therefore, the measure of support for SMEs and services becomes the main generator of investment, especially in the private sphere, along with the other major measure in rural development programmes, which is intended to promote tourism in these areas (Vargas and Mondéjar, 2006). In order to complete this general overview, the application of the shift-share analysis allows to break down the degree of financial implementation into various effects: the global effect, which is associated to the dynamism of private initiative towards investment in SMEs in Castilla-La Mancha, as the average of the aggregates according to counties and funding measures; the structural effect, which may be associated to the different business fabric existing initially in the different counties, which do not attract private capital in the same way due to their heterogeneous nature and the competitive effect, which reflects the differences in how capital is captured in each county in terms of the average for the Autonomous Community with regard to each measure.

\section{AUTHOR BIOGRAPHIES}

Manuel Vargas-Vargas: $\mathrm{PhD}$ in Economics by University of Castilla-La Mancha and Degree in Mathematics by University of Granada. Associate Professor in Statistics at Statistics Department. Faculty of Economics and Business Administration of Albacete, University of Castilla-La Mancha (Spain). Research Interest: State-space models, regional analysis, educational and tourism.

José Mondéjar-Jiménez: European PhD in Economics and Degree in Business Administration by University of Castilla-La Mancha. Degree in Advanced Studies in Statistics at the same university. Assistant Professor in Statistics at Statistics Department. Faculty of Social Sciences of Cuenca. University of Castilla-La Mancha (Spain). Research Interest: State-space models, regional analysis, educational and tourism. 
Juan-Antonio Mondéjar-Jiménez: $\mathrm{PhD}$ and Degree in Business Administration by University of Castilla-La Mancha. Degree in Advanced Studies in Marketing at the same university. Assistant Professor in Marketing at Business Administration Department. Faculty of Social Sciences of Cuenca. University of Castilla-La Mancha (Spain). Research Interest: Consumer behavior, price perception, e-learning and tourism marketing.

María-Leticia Meseguer-Santamaría: Degree in Business Administration by University of Castilla-La Mancha. Assistant Professor in Statistics at Statistics Department. Faculty of Economics and Business Administration of Albacete. University of Castilla-La Mancha (Spain). Research Interest: State-space models, regional analysis, educational and tourism.

\section{REFERENCES}

1. Abad, L. (Coord.) (2006). El patrimonio cultural como factor de desarrollo Estudios multidisciplinares. Ediciones de la Universidad de Castilla-La Mancha, Cuenca.

2. Alfaro, J. L.; Mondéjar, J. \& Vargas, M. (2004). “Análisis de impacto de los programas Proder y Leader en Castilla-La Mancha Medidas de apoyo a pequeñas empresas artesanía y servicios", Revista de desarrollo rural y cooperativismo agrario, 8, 63-76.

3. Dunn, E. (1960). "A statistical and analytical technique for regional analysis", Papers of the Regional Science Association, 6, 97-112.

4. Esteban, A.; Mondéjar, J.; Mondéjar, J. A. \& Meseguer, M.L. (2008). "Análisis de la inversión de los Programas de innovación Rural en patrimonio cultural como elemento dinamizador del turismo", Análisis turístico, 5, 16-29.

5. García, J.L.; Febles, M.F. \& Zapata, V.M. (2005). "La iniciativa comunitaria LEADER en España”. Boletín de la AGE, 39, 361-398.

6. Gómez, M. A.; Mondéjar, J.; Mondéjar, J. A. \& Monsalve, F. (2007). "El turismo rural en los programas de desarrollo en Castilla-La Mancha", en Blanquer, D. (Ed.). Turismo en espacios rurales, 483-502. Tirant Lo Blanch, Valencia.

7. Mayor, M.; López, A. J. \& Pérez, R. (2005). "Escenarios de empleo regional. Una propuesta basada en análisis shift-share”, Estudios de economía aplicada, 23 (3), 863-887.

8. Ministerio de medio ambiente, medio rural y marino (2008). Célula de Promoción y Animación al Desarrollo Rural. Disponible en www.mapya.es.

9. Mondéjar, J.; Mondéjar, J. A.; Monsalve, F. \& Vargas, M. (2007). "Una propuesta de evaluación del impacto de los programas de desarrollo rural Leader y Proder", Ager, Revista de Estudios sobre Despoblación y Desarrollo Rural, 6, 7-26.

10. Mondéjar, J.; Mondéjar, J. A. \& Vargas, M. (2008a). "El turismo rural en cifras: Castilla-La Mancha", TURyDES: Turismo y Desarrollo, 1 (2), 1-11.

11. Mondéjar, J.; Mondéjar, J. A. \& Vargas, M. (2008b). "Análisis del turismo cultural en Castilla-La Mancha (España). El impacto de los programas europeos de desarrollo rural Leader y Proder", Estudios y Perspectivas en Turismo, 17 (3 y 4), 359-373.

12. Mondéjar, J.; Mondéjar, J. A.; Vargas, M. \& Meseguer, M.L. (2008). "Puesta en valor de recursos rurales en los programas de innovación rural en Castilla-La Mancha", Desarrollo local sostenible, 1 (1), 1-11.

13. Vargas, M. \& Mondéjar, J. A. (2006). "Análisis de la inversión de los Fondos Europeos para Desarrollo Rural en Castilla-La Mancha", CLM.Economía, 9, 189-238. 